\title{
Manajemen Pembelajaran Pendidikan Agama Islam di Madrasah Aliyah Negeri Insan Cendikia
}

\author{
Miswar Harahap \\ SD Negeri 101310 Sabanauli \\ e-mail : miswarharahap2014@gmail.com
}

\begin{abstract}
This study aims to describe the management of Islamic religious education learning in MAN IC Tapanuli Selatan by using qualitative methods in descriptive analysis. The results showed that the planning was professional, the implementation was varied, unique, using various learning strategies, then evaluated authentically, while supervision was still carried out by the madrasah head and head of the lecturer in the education sector in the form of examination of learning devices and classroom supervision.
\end{abstract}

Keywords: Management; learning; Islamic education.

\begin{abstract}
Abstrak
Penelitian ini bertujuan untuk mendeskripsikan manajemen pembelajaran pendidikan agama Islam di MAN IC Tapanuli Selatan dengan menggunakan metode kualitatif secara analisis deskriptif. Hasil penelitian menunjukkan bahwa perencanaannya secara profesional,, pelaksanaannya bervariasi, unik, menggunakanberbagai strategi pembelajaran, selanjutnya dievaluasi secara autentik, sedangkan pengawasan tetap dilaksanakan oleh kepala madrasah dan kasi penmad Tapsel berupa pemeriksaan perangkat pembelajaran dan supervisi kelas dengan baik.
\end{abstract}

Kata Kunci: Manajemen; pembelajaran; pendidikan Agama Islam 
Miswar Harahap

\section{Pendahuluan}

Kesadaran orang tua pada pendidikan yang berkualitas untuk anakanaknya semakin meningkat, hal ini dapat dilihat dari banyaknya orang tua yang mencari sekolah yang berkualitas tinggi dan meninggalkan sekolah yang berkualitas rendah. ${ }^{1}$ Kesadaran orang tua tersebut melatarbelakangi munculnya sekolah-sekolah unggulan di setiap kota atau kabupaten. ${ }^{2}$ Sejalan dengan munculnya sekolah-sekolah yang berkualitas tinggi, para peneliti dan pemerhati pendidikan banyak yang melakukan penelitian terhadap manajemen pembelajaran di kelas dalam rangka meninngkatkan mutu sekolah.Oleh karena itu, manajemen pembelajaran perlu digalakkan, sehingga dapat diketahui secara nyata, apa, mengapa dan bagaimana upaya-upaya yang seharusnya dilakukan dalam meningkatkan mutu pembelajaran yang diharapkan. Manajemen pembelajaran perlu dikelola dengan baik agar dapat mencapai hasil yang optimal.

Manajemen pembelajaran merupakan interaksi antara berbagai komponen pengajaran, yang pada hakekatnya dapat dikelompokkan ke dalam tiga komponen utama, yaitu guru, isi atau materi pelajaran dan siswa. ${ }^{3}$ Interaksi antara ketiga komponen tersebut tentu juga melibatkan beberapa unsur yang lain yaitu, sarana-prasarana, metode, media, penataan lingkungan tempat belajar, pembiayaan, dan sistem evaluasi. Ada kecenderungan dewasa ini, untuk kembali pada pemikiran bahwa anak akan belajar lebih baik jika lingkungan diciptakan secara ilmiah. Belajar akan lebih bermakna jika anak mengalami apa yang dipelajarinya,

${ }^{1}$ Endang Listiyani, "Manajemen Pembelajaran Agama Islam Di SMP Nasima Semarang," Educational Management, 1, 1 (2012), hlm. 46-54.

2Madyo Ekosusilo, Supervisi Dalam Latar Buadaya Jawa (Sukoharjo: Unerversitas Bantara, 2003), hlm. 4.

3Muhammad Ali, Guru Dalam Proses Belajar Mengajar (Bandung: Sinar Baru Algesindo, 2002), hlm. 4. 
bukan sekedar mengetahuinya. Pembelajaran yang berorientasi target penguasaan materi terbukti berhasil dalam kompetensi mengingat jangka pendek, tetapi gagal dalam membekali anak memecahkan persoalan dalam kehidupan jangka panjang.

Sufyarman mengutip dari stoner bahwa manajemen adalah proses perencanaan, pengorganisasian, kepemimpinan dan pengendalian upaya anggota organisasi dan penggunaan sumber daya organisasi untuk mencapai tujuan yang telah ditetapkan secara efektif dan efisien. ${ }^{4}$ Dari beberapa pengertian di atas maka dapat disimpulkan bahwa manajemen adalah ilmu yang didasari untuk melakukan sebuah pekerjaan dengan tindakan-tindakan yang terdiri dari perencanaan, pengorganisasian, penggerakan dan pengawasan yang telah ditetapkan dan ditentukan sebelumnya.

Menurut oemar hamalik, pembelajaran adalah suatu kombinasi yang tersusun meliputi unsur-unsur manusiawi material fasilitas, perlengkapandan prosedur yang saling mempengaruhi untuk mencapai tujuan. ${ }^{5}$ Menurut dimyati, pembelajaran adalah kegiatan yang memuat tindakan interaksi antara pembelajaran dan pelajar yang berorientasi pada sasaran belajar yang berakhir dengan evaluasi. ${ }^{6}$ Defenisi lain menyebutkan pembelajaran adalah kegiatan yang bertujuan untuk membelajarkan siswa. ${ }^{7}$

4 Sufyarman, Kapita Selekta Manajemen Pendidikan (Bandung: CV. Alfa Beta, 2004), hlm. 15.

5 Oemar Hamalik, Belajar Dan Pembelajaran (Jakarta: Bumi Aksara, 2001), hlm. 57.

6 Dimiyati and Mujiono, Belajar Dan Pembelajaran (Jakarta: Rineka Cipta, 2005), hlm. 231.

${ }^{7}$ Wina Sanjaya, Strategi Pembelajaran (Jakarta: Kencana, 2007), hlm. 67. 


\section{Miswar Harahap}

Salah satu penyebab munculnya berbagai problematika dalam manajemen pembelajaran adalah praktek mengajar yang lebih memfokuskan kepada penguasaan materi daripada membekali diri siswa dari sudut kompetensi.Padahal secara politik, pendidikan adalah untuk membimbing jiwa dan raga anak didik lewat pengajaran sehingga mereka memiliki kompetensi sesuai bakatnya masing-masing. ${ }^{8}$

Manajemen pendidikan mempunyai tujuan-tujuan yaitu dalam meningkatkan kualitas belajar mengajar.Tanpa manajemen, pendidikan yang baik sulit kiranya bagi lembaga pendidikan untuk berjalan lancar menuju ke arah tujuan pendidikan dan pengajaran yang sempurna yang seharusnya dicapai lembaga tersebut. ${ }^{9}$ Perkembangan dalam Pendidikan Islam memadukan pengajaran informal dan pengajaran non-formal, ${ }^{10}$ sehingga perlu didukungan manajemen pendidikan yang dapat mengakomodir kedua jenis pembelajaran tersebut.

Pendidikan Agama Islam merupakan mata pelajaran yang dikembangkan dari ajaran-ajaran dasar yang terdapat dalam agama Islam. Ajaran-ajaran dasar tersebut terdapat dalam Al-Qur'an dan Al-Hadits. Pendidikan agama islam yang berdasarkan kebutuhan merupakan usaha berupa bimbingan dan asuhan terhadapa siswa agar kelak dapat memahami dan mengamalkan ajaran-ajaran agama islam sebagai jalan hidupnya. ${ }^{11}$ Mata pelajaran Pendidikan Agama Islam tidak hanya

8 Syaiful Sagala, Konsep Dan Makna Pembelajaran (Bandung: Alfabeta, 2009), hlm. 5.

9 Ibrahim Bafadal, Manajemen Peningkatan Mutu SekolahDasar (Jakarta: Bumi Aksara, 2003), hlm. 50.

${ }^{10}$ Rohmat, Teknologi Pembelajaran Perspektif Pendidikan Islam (Yogyakarta: Budi Utama, 2014), hlm. 3.

${ }^{11}$ Hadi Nasroh, "Manajemen Pembelajaran PAI AL-ASASIYYA," Journal Basic Of Education, 02, no. 02 (n.d.), hlm. 78-81. 
mengantarkan peserta didik untuk menguasai berbagai ajaran Islam, tetapi yang terpenting peserta didik dapat mengamalkan ajaran-ajaran itu dalam kehidupan sehari-hari.Mata pelajaran Pendidikan Agama Islam menekankan keutuhan dan keterpaduan antara ranah kognitif, psikomotorik, dan afektifnya. ${ }^{12}$

Pembelajaran pendidikan Agama Islam disekolah, dan juga di madrasah, menuntut sebuah model pembelajaran yang harus menyentuh aspek-aspek potensi berpikir, kejiwaan, tindakan dan bahkan pola hubungan social kemasayarakatandalam sebuah komunitas besar sebagai suatau bangsa. Pendidikan agama islam menuntut keseriusan guru untuk merancang pembelajaran yang dapat secara konperehensif membina dan mengembangkan seluruh aspek kemanusiaa, agarmenjadi insan kamil yang dapatmelaksankan agama dalam seluruh aspek kehidupan manusia, dan masyarakat muslim menjadi komunitas umat amanusia yang paling ideal dimuka bumi ini. ${ }^{13}$ Dengan demikian dibutuhkan kemampuan guru PAI dalam mengelola pembelajaran supaya bisa lebih bermakna kepada sisiwa.

Madrasah Aliyah Negeri Insan Cendikia merupakan madrasah model untuk menyambut tantangan modernisasi sekaligus mempertahankan nilai tradisi pondok pesantren (/slamic boarding schoo).Madrasah Aliyah Negeri Insan Cendikia sebagai madrasah yang mengembangkan sekaligus menyeimbangkan imtak (iman-takwa) dan iptek

${ }^{12 K h o i r o n s y a h, ~ " M a n a j e m e n ~ P e m b e l a j a r a n ~ P e n d i d i k a n ~ A g a m a ~ I s l a m ~ D i ~ S M A ~ N e g e r i ~}$ Pagar Alam," Jurnal An-Nizam 02, no. 01 (April 2017), hlm. 85-100.

13Dede Rosyada, Madrasah Dan Profesinalisme Guru Dalam Arus Dinamika Pendidikan Islam Di Era Otonomi Daerah (Depok: Kencana, 2017), hlm 101. 


\section{Miswar Harahap}

ini tidak dapat dilepaskan dari pemikiran Islam-Modernis. ${ }^{14}$ Berkaitan dengan manajemen pembelajaran Pendidikan Agama Islam di Madrasah Aliyah Negeri Insan Cendikia Kecamatan Sipirok peneliti melakukan studi awal dan menemukan bahwa para guru di MAN IC Tapanuli Selatan sangat memperhatikan manajemen pembelajaran.Dengan adanya studi pustaka awal maka peneliti melakukan penelitian tentang manajemen pembelajaran Pendidikan Agam Islam di Man IC Tapanuli Selatan.

\section{Metode penelitian}

Metode yang digunakan dalam penelitian ini adalah penelitian deskriptif. Sumber data menggunakan sumber data primer dan skunder. Adapun teknik pengumpulan data yang digunakan adalah observasi, wawancara, dan dokumentasi.Teknik pengecekan data untuk memperkuat penenlitian ini adalah, ketekunan/keajegan pengamatan, dan triangulasi data. Adapaun teknik analisis data yang dilakukan yaitu reduksi data, penyajian data, dan penarikan kesimpulan.

\section{Hasil dan pembahasan}

Dalam melaksanakan proses pembelajaran seorang guru dituntut untuk memiliki kemampuan memanajemen pembelajaran agar tujuan pemebelajaran dapat tercapai secara efektif dan efiisen. Manajemen pembelajaran dalam penelitian ini merupakan segala aktivitas yang berkaitan dengan perencanaan pembelajaran , pelaksanaan pembelajaran, penilaian (evaluasi) pembelajaran dan pengawasan pembelajaran di Madrasah Aliyah Negeri Insan Cendikia Tapanuli Selatan. Dalam hal ini

\footnotetext{
${ }^{14}$ Makmuri Sukarno, "Mengembangkan Madrasah Aliyah Negeri Insan Cendekia Untuk Menjawab Tantangan Modernisasi, Demokratisasi Dan Globalisasi," Jurnal Kependudukan Indonesia 09, no. 02 (Desember 2014): hlm119. 
manajemen pembelajaran yang dimaksud adalah khusus pendidikan agama Islam yang terdiri dari pelajaran Al Quran Hadis, Akidah Akhlak, Fikih, dan Sejarah Kebudayaan Islam. Setelah dilaksanakan penelitian dapat diketahui bahwa manajemen pembelajaran pendidikan agama Islam di Madrasah Aliyah Negeri Insan Cendikia Tapanuli Selatan adalah sebagai berikut : 1. Perencanaan Pembelajaran Pendidikan Agama Islam di Madrasah Aliyah Negeri Insan Cendikia Tapanuli Selatan. Berdasarkan hasil wawancara dan obeservasi yang peneliti lakukan ditemukan bahwa semua guru PAI di MAN IC Tapanuli Selatan wajib menyusun perangkat pembelajaran yang merupakan bagian dari perencanaan pembelajaran, yang terdiri dari silabus, prota, prosem, analisis materi pelajaran, KKM, sampai dengan RPP dan penilaian. Hal ini sejalan dengan pendapat yang dikemukakan oleh E. Mulyasa yaitu sebelum melaksanakan pembelajaran guru harus membuat perencanaan terlebih dahulu yang memuat silabus, prota, prosem`, analisis materi pelajaran, KKM, sampai dengan RPP dan penilaian. ${ }^{15}$

Pelaksanaan Pembelajaran Pendidikan Agama Islam di Madrasah Aliyah Negeri Insan Cendikia Tapanuli Selatan. Adapun pelaksanaan pembelajaran yang dilakukan di MAN IC Tapanuli Selatan dimulai dari pengelolaan kelas. Pengelolaan kelas di Madrasah Aliyah Insan Cendikia Tapanuli Selatan dilakukan sesuai dengan kebutuhan dan latar belakang peserta didik yang berbeda-beda, dalam mengolah kelas guru memposisikan tempat duduk, volume intonasi bisa didengar baik oleh santri, guru menggunakan kata-kata santun, guru menyesuaikan materi pelajaran sesuai kemampuan santri, guru menciptakan ketertiban, guru

15 E Mulyasa, Implementasi Kurikulum 2004, Panduan Pembelajaran KBK (Bandung: Remaja Rosdakarya, 2005), hlm. 27. 


\section{Miswar Harahap}

memberikan penguatan, guru mendorong agar santri bertanya dan menghargai pendapat santri, guru berpakaian sopan, rapi dan bersih serta guru mengakhiri dengan yang disesuaikan. Selain itu dalam mengelola kelas sebagai guru berusaha menciptakan lingkungan yang kondusif dan memberikan berbagai pelayanan kepada peserta didik dalam proses belajar mengajar, diantaranya memberikan pembelajaran remedial bagi peserta didik yang kurang berprestasi atau berprestasi rendah, menciptakan suasana kerjasama, melibatkan peserta didik dalam proses perencanaan belajar dan pembelajaran.

Berdasarkan hasil wawancara dan observasi yang peneliti lakukan, pengelolaan kelas merupakan hal yang sangat penting di MAN Insan cedidikia Tapanuli Selatan. Selain masalah penataan kelas dan sikap guru, guru juga sangat memperhatikan kondisi peserta didik.Hal ini sejalan dengan pendapat Abdul Majid yaitu dalam pengelolaan kelas seorang guru harus menciptakan iklim belajar yang kondusif salah satunya sarana, pengaturan lingkungan, penampilan dan sikap guru, hubungan yang harmonis antar peserta didik dengan guru dan diantara peserta didik, serta penataan organisasi dan bahan pembelajaran secara tepat, sesuai dengan kemapuan dan perkembangan peserta didik. ${ }^{16}$

Adapun tahap implikasi pelaksanaan pembelajaran yang di MAN IC diawali tahap pra intruksional. Dalam tahap ini guru PAl telah melakukan pembiasaan untuk senantiasa berdoa bersama peserta didik sebelum melaksanakan sebuah proses pembelajaran. Dan setelah itu menanyakan kehadiran peserta didik, serta melakukan pre test baik berupa tanya jawab, kuis atau yang lainnya. Kemudian masuk ke kegiatan intruksional yaitu dimulai dengan membuka buku masing-masing sebagai sumber

16Abdul Majid, Perencanaan Pembelajaran Pengembanagn Standar Kompetensi Guru (Bandung: Remaja Rosdakarya, 2005), hlm 165. 
pembelajaran yang paling utama. Buku merupakan hal yang harus selalu ada dalam setiap pembelajaran madrasah, mengingat bahan kajiannya berupa ilmu agama yang didalamnya merupakan ajaran-ajaran yang bersifat mutlak. Adapun mengenai kegiatan penutup, evaluasi dan tindak lanjut. Guru PAI di MAN IC Tapanuli Selatan melakukan kegiatan penutup dalam pembelajaran PAI. Dalam tahap ini kami selalu memberikan penguatan atau kesimpulan tentang pembelajaran yang sudah dijalani. Pemberian penguatan atau kesimpulan tentang materi pembelajaran kepada peserta didik akan berguna memberikan pemahaman yang lebih terkait dengan pembahasan selama proses pembelajaran, hal ini dikarenakan ada sebagian peserta didik yang baru dapat memahami suatu pengetahuan dari sebuah kesimpulan yang diberikan oleh seorang guru. Setelah peserta didik faham dan mengerti materi yang disampaikan oleh guru, biasanya guru memberikan latihan kepada peserta didik agar peserta didik ebih faham tentang materi yang sudah dipelajari. Kemudian guru bersama peserta didik akan mengoreksi hasil jawaban peserta didik, dan aka dilakukan refleksi bersama peserta didik. Setelah semua diselesaikan maka kegiatan terakhir adalah pembacaan do'a bersama.

Berdasarkan hasil wawancara peneliti dengan guru PAI dan peserta didik di MAN IC, dapat dilihat bahwa guru-guru tersebut telah melaksanakan tahapan-tahapan pelaksanaan secara umum yakni pra intruksional, intruksional, pasca inturksional, evaluasi dan tindak lanjut. Hal ini telah sesuai dengan UUD no 22 tahun 2016 yaitu tentang standar proses. Terkait pembelajaran bermakna, para guru PAI sudah berusaha menciptakan pembelajaran yang bermakna. Baik dengan menggunakan stretegi, model, metode, dan teknik pembelajaran. Selain itu guru juga menggunakan media dan mengaitkan materi dengan kehidupan seharihari. Hal ini sejalan dengan pendapat Mujammil Qomar bahwa 


\section{Miswar Harahap}

penggunaan media dapat meningkatkan proses interaksi guru dengan peserta didik dan interaksi peserta didik dengan lingkungannya. ${ }^{17}$

Penilaian (evalution) Pembelajaran Pendidikan Agama Islam di Mandrasah Aliyah Insan Cendikia Tapanuli Selatan. Penilaian pembelajaran diselenggarakan guna mengetahui sejauh mana tingkat keberhasilan pencapaian tujuan pembelajaran. Berdasarkan hasil wawancara dengan guru PAI dapat dilihat bahwa tujuan para guru PAI melaksanakan penilaian adalah untuk mengetahui perkembangan peserta didik. Hal ini sejalan dengan pendapat Abdul Majid bahwa penilaian bertujuan untuk mengetahui apakah peserta didik telah menguasai seluruh kompetensi yang ada dalam kurikulum. ${ }^{18}$

Terkait penilaian yang dilaksanakan, guru PAI sudah melakukan penilaian yang mengacu pada kurikulum 2013 yaitu penilaian autentik. Hal ini sejalan dengan Permendikbud Nomor 66 Tahun 2013 tentang Standar Penilaian. Adapun aspek yang dinilai adalah aspek kognitif, afektif, dan psikomotorik. Dalam penilaian kognitif selain penilaian harian, penilaian yang lainnya seperti penilaian tengah semester dan penilaian akhir semester sudah terjadwal. Dan waktunya sesuai dengan jadwal yang dikeluarkan oleh kementrian agama.

Mengenai instrumen penilaian dan hal-hal yang dipertimbangkan dalam pembuatan instrumen, bahwa instrumen yang digunakan guru PAI dalam penilaian adalah tes dan non tes. Dimana tes digunakan dengan secara tertulis dan diperuntukkan untuk mengukur kemampuan kognitif peserta didik. Sedangkan non tes yang digunakan adalah lembar observasi

17 Mujammil Qomar, Manajemen Pembelajaran Pendidikan Agama Islam (Jakarta: Erlangga, 2018), hlm. 180-185.

18 Abdul Majid, Belajar Dan Pembelajaran Pendidikan Agama Islam (Bandung: Remaja Rosdakarya, 2014), hlm. 315. 
yang diperuntukkan mengukur aspek afektif. Hal ini sejalan dengan pendapat Mulyasa mengenai instrumen penilaian yaitu alat penilaian hendaknya komprehensif yang meliputi tes dan non tes, sehingga diperoleh gambaran hasil belajar yang obyektif. ${ }^{19}$

Dalam menyampaikan hasil penilaian, para guru PAI menyampaikan hasil penilaiannya kepada peserta didik. Hanya saja dalam menyampaikan hasil penilaiannya ada yang berbeda antara guru. Dimana dalam menyampaikan hasil penilaian harian guru langsung membagikan lembar jawaban peserta didik, dan untuk penilaian tengah semester dan penilaian akhir semester guru menyampaikan penilaian secara langsung. Dan untuk tindak lanjut dari penilaian semua guru PAI menindaklanjuti dari penilaian yang dilakukan dengan cara remedial bagi peserta didik yang tidak mencapai nilai KKM. Hal ini sejalan dengan pendapat Suryosubroto bahwa Program perbaikan dan pengayaan dalam pengajaran sangat diperlukan dalam rangka pelaksanaan pola belajar tuntasketuntasan belajar adalah pencapaian taraf penguasaan minimalyang ditetapkan bagi setiap unit bahan pelajaran baik secara perorangan maupun kelompok. 20

Pengawasan (controlling) Pembelajaran Pendidikan Agama Islam di Madrasah Aliyah Negeri Insan Cendikia Tapanuli Selatan. Pengawasan merupakan proses yang terus-menerus dilakukan untuk menjamin terlaksananya perencanaan pendidikan secara konsekuen. Controlling (pengawasan) merupakan langkah penentu terhadap apa yang harus dilaksanakan, sekaligus menilai dan memperbaiki, sehingga pelaksanaannya sesuai dengan rencana serta tercapainya tujuan secara

19 E Mulyasa, Implementasi Kurikulum 2004, Panduan Pembelajaran KBK

(Bandung: Remaja Rosdakarya, 2005), hlm. 174.

20 B Sryosubroto, Proses Belajar Mengajar Di Sekolah, IV (Jakarta: Rineka Cipta, 2006), hlm. 56. 


\section{Miswar Harahap}

efektif dan efisien.Monitoring hanya dilakukan oleh kepala sekolah dan pengawas dari kemenag. Dan untuk jadwal monitoring kepala sekolah biasanya dilaksanakan sekali dalam sebulan. Dan untuk satu semester berarti monitoring dilakukan sebanyak enam kali. Monitoring yang dilaksanakan oleh kepala sekolah langsung masuk ke dalam kelas dan memantau guru dan peserta didik langsung ke dalam kelas. Dan untuk pengawas biasanya monitoring dilakuakn sekali dalam 3 bulan.

Monitoring dilaksanakan dengan mengunjungi beberapa kelas, dan selainnya dilaksanakan monitoring terhadap guru secara bersama-sama. Dari pembahasan di atas dapat ditarik kesimpulan bahwa kepala sekolah telah melaksanakan tugasnya sebagai peminpin di dalam sebuah lembaga formal. Dimana, kepala sekolah melakukan pengawasan terhadap semua guru salah satunya monitoring. Hal ini sejalan dengan pendapat Zainal Aqib bahwa salah satu tugas kepala sekolah adalah mengawasi pekerjaan yang dilakukan para guru, yaitu memonitoring langsung ketika guru melaksanakan kegiatan pembelajaran. ${ }^{21}$

Terkait supervisi yang dilakukan oleh kepala MAN IC Tapanuli Selatan terhadap para guru PAI dapat dilihat bahwa supervisi dilakukan sekali dalam dua bulan. Dan untuk pemberian masukan-masukan biasanya kepala sekolah langsung memanggil guru yang bersangkutan untuk mengahadap kepala sekolah. Dan pernyataan guru tersebut juga diperkuat oleh kepala sekolah, bahwa kepala sekolah melakukan supervisi sekali dalam 2 bulan/. Jadi total supervisi yang dilakukan kepala sekolah dalam satu semester adalah 3 kali.

Adapun hal-hal yang disupervisi yaitu perangkat pembelajaran guru mulai dari silabus, RPP, Prota, Prosem, dan penilaian, selain itu kepala

21 Zainal Aqib, Manajemen Lembaga Pendidikan Islam (Bandung: PT. Sarana Tutorial Nurani Sejahtera, 2015), hlm. 110. 
sekolah juga melakukan supervisi terhadap proses pembelajaran yang sedang berlangsung. Hal ini sejalan dengan tugas kepala sekolah sebagai supervisor yaitu pengendalian dalam bentuk supervisi kelas dengan cara melakukan pembinaan-pembinaan terhadap proses pelaksanaan pembelajaran berlangsung didalam kelas dan supervisi secara klinis, yaitu melakukan pembinaan kepada guru yang bersangkutan baik dilakukan di ruang kepala sekolah maupun dalam rapat dinas dewan guru. ${ }^{22}$

\section{Penutup}

Dari penelitian yang telah dilaksanakan oleh peneliti berkaitan dengan Manajemen Pembelajaran Pendidikan Agama Islam di MAN Insan Cendikia Tapanuli Selatan Kecamatan Sipirok maka hasi yang diperoleh adalah sebagai berikut: Perencanaan pembelajaran pendidikan agama Islam di MAN Insan Cendikia Tapanuli Selatan sudah sejalan dengan teori dan juknis dari Kementerian Agama. Dan keunikan perencanaan pembelajaran yang dipersiapkan guru-guru PAI MAN IC adalah sudah berbasis aplikasi. Ini menunjukan MAN IC Tapanuli Selatan sudah memiliki kelebihan dalam hal menyusun perencanaan pembelajaran dibandingkan dengan madrsah lainnya. Pelaksanaan pembelajaran pendidikan agama Islam di MAN Insan Cendikia Tapanuli Selatan telah terlaksana secara efektif dan efisien. Kemampuan guru-guru PAI MAN IC Tapauli Selatan dalam mengaplikasikan berbagai macam model, pendekatan, strategi dan metode pembelajaran sudah cukup bagus dan menarik. Evaluasi pembelajaran pendidikan agama Islam di MAN Insan Cendikia Tapanuli Selatan sudah berjalan secara objektif. Penilaian yang dilaksanakan oleh

22 Khoironsyah, "Manajemen Pembelajaran Pendidikan Agama Islam Di SMA Negeri Pagar Alam," Jurnal An-Nizam 02, no. 01 (April 2017), hlm. 85-100. 


\section{Miswar Harahap}

guru MAN IC adalah penilaian autentik, yaitu penilaian proses dan hasil yang meliputi tiga aspek apektif, kognitif, dan psikomotorik.

Pengawasan pembelajaran pendidikan agama Islam di MAN Insan Cendikia Tapanuli Selatan sudah berjalan dengan baik dan memberi efek yang baik bagi guru, karena dengan adanya pengawasan tersebut, guruguru PAI mempersiapkan diri sebaik mungkin. Di samping itu MAN IC Tapanuli Selatan menjadi salah satu MAN percontohan di Sumatera Utara, ini menunjukkan bahwa MAN IC Tapanuli Selatan memiliki kelebihan dibanding MAN yang lain. Dan yang perlu dikembangkan dan diteliti di MAN IC Tapanuli Selatan iini adalah berhubungan dengan manajemen kelas dan manajemen peserta didik.

\section{Daftar Pustaka}

Ali, Muhammad. Guru Dalam Proses Belajar Mengajar. Bandung: Sinar Baru Algesindo, 2002.

Aqib, Zainal. Manajemen Lembaga Pendidikan Islam. Bandung: PT. Sarana Tutorial Nurani Sejahtera, 2015.

Bafadal, Ibrahim. Manajemen Peningkatan Mutu SekolahDasar. Jakarta: Bumi Aksara, 2003.

Dimiyati, and Mujiono. Belajar Dan Pembelajaran. Jakarta: Rineka Cipta, 2005.

Ekosusilo, Madyo. Supervisi Dalam Latar Buadaya Jawa. Sukoharjo: Unerversitas Bantara, 2003. 
Manajemen Pembelajaran Pendidikan Agama Islam.....

Hamalik, Oemar. Belajar Dan Pembelajaran. Jakarta: Bumi Aksara, 2001.

Khoironsyah. "Manajemen Pembelajaran Pendidikan Agama Islam Di SMA Negeri Pagar Alam." Jurnal An-Nizam 02, no. 01 (April 2017): 85100.

Listiyani, Endang. "Manajemen Pembelajaran Agama Islam Di SMP Nasima Semarang." Educational Management, 1, 1 (2012): 46-54.

Majid, Abdul. Belajar Dan Pembelajaran Pendidikan Agama Islam. Bandung: Remaja Rosdakarya, 2014.

Perencanaan Pembelajaran Pengembanagn Standar Kompetensi Guru. Bandung: Remaja Rosdakarya, 2005.

Mulyasa, E. Implementasi Kurikulum 2004, Panduan Pembelajaran KBK. Bandung: Remaja Rosdakarya, 2005.

Nasroh, Hadi. "Manajemen Pembelajaran PAI AL-ASASIYYA." Journal Basic Of Education, 02, no. 02 (n.d.), 78-81.

Qomar, Mujammil. Manajemen Pembelajaran Pendidikan Agama Islam. Jakarta: Erlangga, 2018.

Rohmat. Teknologi Pembelajaran Perspektif Pendidikan Islam. Yogyakarta: Budi Utama, 2014. 
Miswar Harahap

Rosyada, Dede. Madrasah Dan Profesinalisme Guru Dalam Arus Dinamika Pendidikan Islam Di Era Otonomi Daerah. Depok: Kencana, 2017.

Sagala, Syaiful. Konsep Dan Makna Pembelajaran. Bandung: Alfabeta, 2009.

Sanjaya, Wina. Strategi Pembelajaran. Jakarta: Kencana, 2007.

Sryosubroto, B. Proses Belajar Mengajar Di Sekolah. IV. Jakarta: Rineka Cipta, 2006.

Sufyarman. Kapita Selekta Manajemen Pendidikan. Bandung: CV. Alfa Beta, 2004.

Sukarno, Makmuri. "Mengembangkan Madrasah Aliyah Negeri Insan Cendekia Untuk Menjawab Tantangan Modernisasi, Demokratisasi Dan Globalisasi." Jurnal Kependudukan Indonesia 09, no. 02 (Desember 2014), 119. 